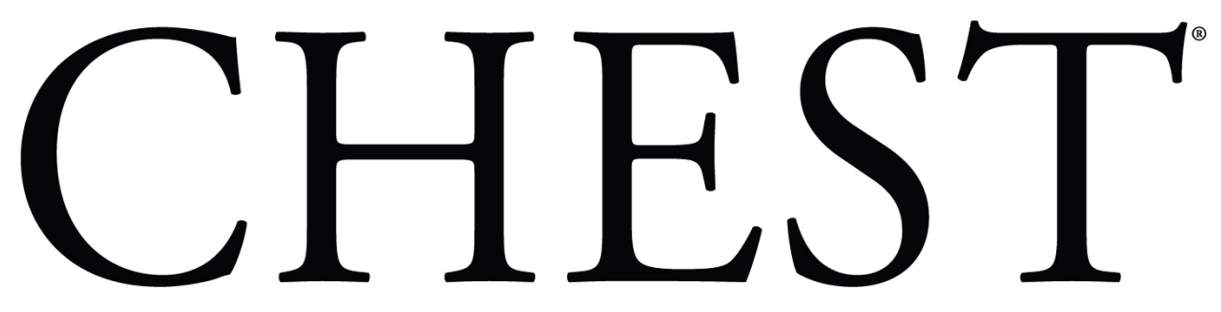

Official publication of the American C ollege of Chest Physicians Insertion/Deletion Polymorphism and Risk and Outcome of Pneumonia

Ewoudt M. W. van de Garde, Henrik Endeman, Vera H. M. Deneer, Douwe H. Biesma, Fakhredin A. Sayed-Tabatabaei, Henk J. T. Ruven, Hubert G. M. Leufkens and Jules M. M. van den Bosch

Chest 2008;133;220-225; Prepublished online October 1, 2007; DOI 10.1378/chest.07-1400

The online version of this article, along with updated information and services can be found online on the World Wide Web at: http://chestjournal.org/cgi/content/abstract/133/1/220

CHEST is the official journal of the American College of Chest Physicians. It has been published monthly since 1935. Copyright 2007 by the American College of Chest Physicians, 3300 Dundee Road, Northbrook IL 60062. All rights reserved. No part of this article or PDF may be reproduced or distributed without the prior written permission of the copyright holder

(http://www.chestjournal.org/misc/reprints.shtml). ISSN: 0012-3692.

A M E R I C A N C O L L E G E O F

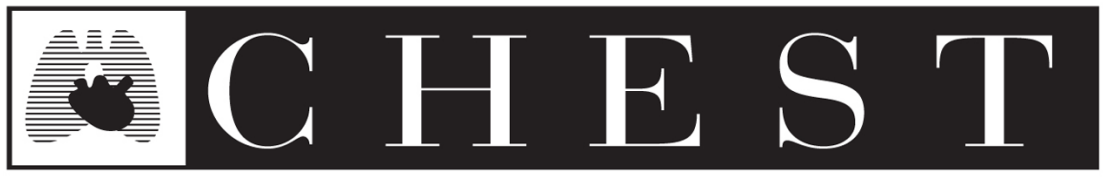

$\begin{array}{llllllllll}\mathrm{P} & \mathrm{H} & \mathrm{Y} & \mathrm{S} & \mathrm{I} & \mathrm{C} & \mathrm{I} & \mathrm{A} & \mathrm{N} & \mathrm{S}\end{array}$ 


\title{
Angiotensin-Converting Enzyme Insertion/Deletion Polymorphism and Risk and Outcome of Pneumonia*
}

\author{
Ewoudt M. W. van de Garde, PharmD, PhD; Henrik Endeman, MD; \\ Vera H. M. Deneer, PharmD, PhD; Douwe H. Biesma, MD, PhD; \\ Fakhredin A. Sayed-Tabatabaei, MD, PhD; Henk J. T. Ruven, PhD; \\ Hubert G. M. Leufkens, PharmD, PhD; and \\ Jules M. M. van den Bosch, MD, PhD, FCCP
}

\begin{abstract}
Background: Recent studies have suggested involvement of the angiotensin-converting enzyme (ACE) insertion/deletion (I/D) polymorphism in the susceptibility to and severity of communityacquired pneumonia (CAP) in Asian populations. We have explored the hypothesis that the ACE I/D polymorphism affects the risk and outcome of CAP in a Dutch white population.

Methods: This is a hospital-based prospective observational study including patients with CAP admitted between October 2004 and August 2006. All patients were genotyped, and pneumonia severity and clinical outcome were compared between patients with II, ID, and DD genotypes of the ACE gene. Pneumonia severity was assessed on day of hospital admission and consecutively on days $2,3,5$, and 10 of hospital stay using the acute physiology score (APS). Outcomes evaluated were duration of hospital stay, ICU admittance, and in-hospital and 28-day mortality rates. To study the association between ACE genotype and risk of pneumonia, the distribution of the ACE I/D polymorphism was compared with healthy control subjects from the same geographic region. Results: In total, 200 patients with pneumonia and 200 control subjects were included in the study. Mean age of the patients was 63 years. APS scores were not different between the genotype groups on any of the days, and all clinical outcomes (duration of hospital stay, ICU admittance, in-hospital and 28-day mortality rates) were comparable between the three genotype groups. The ACE I/D genotype distribution was identical for patients and control subjects $(p=0.973)$.

Conclusions: The ACE I/D polymorphism is not associated with risk and outcome of CAP in the Dutch white population.

(CHEST 2008; 133:220-225)
\end{abstract}

Key words: angiotensin-converting enzyme; genetic polymorphisms; outcome assessment; pneumonia

Abbreviations: $\mathrm{ACE}=$ angiotensin-converting enzyme; APS = acute physiology score; $\mathrm{CAP}=$ community acquired pneumonia; $\mathrm{CI}=$ confidence interval; $\mathrm{I} / \mathrm{D}=$ insertion/deletion; $\mathrm{PCR}=$ polymerase chain reaction; $\mathrm{PSI}=$ pneumonia severity index

C ommunity-acquired pneumonia (CAP) ranks in the top-10 leading causes of death, with estimated mortality rates varying between $5 \%$ and $20 \% .^{1,2}$ Despite substantial progress in standards of care and the availability of prediction rule models to identify patients at high risk, ${ }^{3}$ the mortality rate and impact of pneumonia on health remain high., 4 Therefore, it is considered that, besides demographics and comorbidities, genetic factors play an important role in the susceptibility to and severity of pneumonia.

Recently, the involvement of the renin-angiotensin system in the pathogenesis and evolution of pneumonia has gained substantial interest. The use of angiotensin-converting enzyme (ACE) inhibitors has been associated with lower risk of pneumonia, particularly in elderly patients, and patients using ACE inhibitors are less likely to die from pneumonia. ${ }^{6-8}$ ACE inhibitors may act on the pathogenesis of pneumonia in two different ways: first, they induce the cough reflex through inhibition of the degradation of the protussive peptides bradykinin and 
substance $\mathrm{P}^{9,10}$; and second, they have an immunomodulatory effect through lowering angiotensin-II levels. ${ }^{11-16}$ Serum ACE levels are also determined genetically through the identified insertion/deletion (I/D) polymorphism in intron 16 of the ACE gene. The I/D polymorphism has been reported to account for $47 \%$ of the variance in serum ACE level, whereas the DD genotype is associated with the highest levels of serum ACE. 17

The ACE I/D polymorphism can also been linked to pneumonia because persons with the DD genotype have a lower cough reflex compared with II and ID, ${ }^{18,19}$ and the DD genotype carriers have higher serum levels of the proinflammatory angiotensin-II. ${ }^{20}$ Morimoto et $a^{21}$ already showed that the ACE D allele is an independent risk factor for (fatal) pneumonia in an Asian population. We have explored the hypothesis that the ACE I/D polymorphism affects the risk and clinical outcome of CAP in a Dutch white population.

\section{Materials AND Methods}

\section{Study Design and Subjects}

The study was conducted in St. Antonius Hospital, a 600-bed teaching hospital (Nieuwegein, the Netherlands), and was approved by the local Medical Ethics Committee. Informed consent was obtained from each subject. The ethnicity of the population in and around the city of Nieuwegein is primarily (>94\%) white. ${ }^{22}$

This was a prospective observational study of patients with confirmed pneumonia admitted between October 1, 2004, and August 1, 2006. Pneumonia was defined as a new or progressive infiltrate on a chest radiograph plus at least two of the following criteria: cough; sputum production; temperature $>38^{\circ} \mathrm{C}$ or $<35^{\circ} \mathrm{C}$; ausculatory findings consistent with pneumonia, leukocytosis, or leukopenia ( $>10 \mathrm{~g} / \mathrm{L},<4 \mathrm{~g} / \mathrm{L}$, or $>10 \%$ rods in leukocyte differentiation); and C-reactive protein greater than three times the upper limit of normal. Patients who were immune compromised (systemic steroid use at hospital admission [prednisone equivalent $>20 \mathrm{mg} / \mathrm{d}$ for $>3$ days], hematologic malignancies, and other immunosuppressive therapy) were excluded.

${ }^{*}$ From the Departments of Clinical Pharmacy (Drs. van de Garde and Deneer), Internal Medicine (Drs. Endeman and Biesma), Clinical Chemistry (Dr. Ruven), and Pulmonary Medicine (Dr. van den Bosch), St. Antonius Hospital, Nieuwegein; Utrecht Institute for Pharmaceutical Sciences (Dr. Leufkens), Utrecht University, Utrecht; and Medicines Evaluation Board (Dr. Sayed-Tabatabaei), The Hague, the Netherlands.

The authors have no conflicts of interest to disclose.

Manuscript received June 5, 2007; revision accepted August 6, 2007.

Reproduction of this article is prohibited without written permission from the American College of Chest Physicians (www.chestjournal. org/misc/reprints.shtml).

Correspondence to: Ewoudt M. W. van de Garde, PhD, Utrecht Institute for Pharmaceutical Sciences, Faculty of Science, Utrecht University, Sorbonnelaan 16, 3583 CA, Utrecht, the Netherlands; e-mail: e.m.w.vandegarde@uu.nl

DOI: 10.1378/chest.07-1400
Microbiological confirmation was sought using sputum for Gram-stain and sputum and blood for culture. Sputum was analyzed by polymerase chain reaction (PCR) for atypical pathogens (Mycoplasma pneumoniae, Legionella pneumophila, and Chlamydophyla psittaci). Urine was sampled for antigen testing on Streptococcus pneumoniae and L pneumophila. In addition, serum samples of the day of hospital admission and day 10 were analyzed in pairs for detection of a fourfold rise of antibodies to respiratory viruses, Coxiella burnetii, $M$ pneumoniae, and $C$ psittaci by complement fixation assay. Pharyngeal samples were taken for viral culture.

As control group, ACE I/D genotype data were used from a population of healthy employees of the St. Antonius Hospital who volunteered for venapunction. All control subjects were Dutch and white. Other characteristics of this population have been described elsewhere. ${ }^{23}$ The control subjects did not have a history of pneumonia.

\section{Sample-Size Calculation}

In the recent study of Morimoto et al, ${ }^{21}$ the relative risks (DD vs II+ID) were 2.9 for pneumonia and 4.4 for fatal pneumonia. To detect a clinical significant effect of ACE I/D polymorphism on pneumonia outcome, we hypothesized that carriers with the DD genotype of the ACE gene would have a threefold-increased mortality risk compared with carriers of the II and ID genotypes. Considering a baseline mortality risk of $10 \%$ combined with $25 \%$ DD genotype carriers, this resulted in a estimated sample size of 196 patients $(\alpha=0.05$, power $=0.80)$. For the effect of the ACE polymorphism on the susceptibility for pneumonia, considering a relative risk for pneumonia of 2 for carriers of the DD genotype compared with $\mathrm{II}+\mathrm{ID},{ }^{21}$ the required sample size to detect a significant effect of genotype on pneumonia risk was estimated at 153 patients and 153 control subjects $(\alpha=0.05$, power $=0.80)$. Beforehand, the aim of the present study was set at the inclusion of 200 patients and 200 control subjects.

\section{Outcome Measures and Illness Severity Assessment}

The following outcome measures were identified for all patients: duration of hospital stay, need for intensive care admittance, survival to hospital discharge, and 28-day mortality. To quantify illness severity, the acute physiology score (APS) score was calculated for each patient on hospital admission and consecutively on days $2,3,5$, and 10 of hospital stay. ${ }^{24}$ In addition, for each patient the highest APS score during hospital stay and the occurrence of ARDS were identified.

\section{Genotyping}

Genomic DNA of patients was isolated from ethylenediamine tetra-acetic acid blood (MagNA Pure LC DNA Isolation kit 1, MagNA Pure; Roche Diagnostics; Basel, Switzerland). ACE I/D polymorphisms were determined by real-time PCR using fluorescent hybridization probes and a LightCycler (Roche Diagnostics) as described earlier with some slight modifications. ${ }^{17,25,26}$ Briefly, the reaction volume was $20 \mu \mathrm{L}$, containing $1 \mu \mathrm{L}$ of DNA (40 to $80 \mathrm{ng}$ ), $0.2 \mu \mathrm{mol} / \mathrm{L}$ forward primer and $0.8 \mu \mathrm{mol} / \mathrm{L}$ reversed primer reported by Rigat et al, ${ }^{17} 2 \mu \mathrm{L}$ of $10 \times$ reaction buffer (LightCycler DNA master hybridization probes; Roche Diagnostics; Basel, Switzerland), $1.6 \mu \mathrm{L}$ of $25 \mathrm{mmol} / \mathrm{L} \mathrm{MgCl}_{2}$ stock solution, and $0.1 \mu \mathrm{mol} / \mathrm{L}$ of each probe. The detection probes were the same as described by Somogyvari et al. ${ }^{26}$ PCR conditions were as follows: denaturation at $95^{\circ} \mathrm{C}$ for $60 \mathrm{~s}$, followed by 50 cycles denaturation $\left(95^{\circ} \mathrm{C}\right.$ for $\left.10 \mathrm{~s}\right)$, annealing (first 10 cycles: $67^{\circ} \mathrm{C}$ for $20 \mathrm{~s}$, followed by $0.5^{\circ} \mathrm{C}$ stepwise 
decrease per cycle to $\left.61^{\circ} \mathrm{C}\right)$, and extension $\left(72^{\circ} \mathrm{C}\right.$ for $30 \mathrm{~s}$ ). Melting curve analysis consisted of heating to $95^{\circ} \mathrm{C}$ for $5 \mathrm{~s}, 45^{\circ} \mathrm{C}$ for $60 \mathrm{~s}$, followed by an increase of the temperature to $75^{\circ} \mathrm{C}$ at $0.2^{\circ} \mathrm{C} / \mathrm{s}$. To exclude mistyping of $\mathrm{I} / \mathrm{D}$ heterozygotes as $\mathrm{D} / \mathrm{D}$ homozygotes, a second PCR reaction was conducted under the same conditions except for using the primer pair as described earlier. ${ }^{25,26}$ Verification of the real-time PCR results with those of electrophoresis and using sequence-specific primers-PCR revealed no mistyping. ACE I/D polymorphisms were determined after follow-up of the patients, excluding confounding by indication.

\section{Comorbidity Assessment}

Besides ACE genotyping, comorbidities were identified to address factors related with outcome in CAP. Comorbidities were defined based on the presence of conditions for which the patient was under active medical supervision or was receiving treatment at the time of hospital admission. Comorbidities evaluated were lung diseases (COPD or treated asthma), congestive heart failure, diabetes (both type I and type II), and end-stage renal disease (serum creatinine $>150 \mu \mathrm{mol} / \mathrm{L}$ ). Furthermore, patients were classified according to the pneumonia severity index (PSI) developed by Fine et al. ${ }^{3}$ The use of ACE inhibitors and angiotensin-II receptor blockers was also assessed.

\section{Statistical Analysis}

Statistical software (SPSS version 12.0.1 for Windows; SPSS; Chicago, IL) was used for statistical analysis. Continuous data were expressed as mean $\pm \mathrm{SD}$ or median (range) when appropriate. Categorical data were analyzed by $\chi^{2}$ and continuous data by Student $t$ test, rank tests, and one-way analysis of variance when appropriate. Multivariate logistic regression analyses were applied to study the association between ACE genotype and need for ICU admittance, in-hospital mortality, and 28-day mortality. All baseline characteristics were considered potential prognostic factors for clinical outcome. Nonsignificant variables $(\mathrm{p}>0.05)$ were removed stepwise from the model. $\chi^{2}$ tables were used to compare the observed number of each genotype with those expected for a population in Hardy-Weinberg equilibrium and to compare genotype frequencies between the patients with pneumonia and the control subjects. For all tests, $\mathrm{p} \leq 0.05$ was considered significant.

\section{RESULTS}

In total, 201 patients with pneumonia and 200 control subjects were included in the study. For one patient, a DNA sample was missing, leaving 200 patients and 200 control subjects eligible for further analysis.

There were no major differences in demographics and clinical characteristics of the patients by ACE genotype (Table 1). Based on microbiological data, the patients were categorized as pneumococcal pneumonia, atypical pneumonia, pneumonia with Gram negative strain, viral pneumonia, or etiology unknown. In total, etiology was available for 127 patients (64\%). Etiology was not different for the three ACE genotype groups (Table 1). The overall median duration of hospital stay was 9.5 days, and 21 patients were admitted to the intensive care ward (Table 2). During hospital stay, 10 patients died, all due to pneumonia. The overall 28 -day mortality rate was $5.0 \%$ and was not statistically different between the three ACE genotypes (7.1\%, 3.8\%, and $5.8 \%$ for II, ID, and DD, respectively; $\mathrm{p}=0.668$ ). The mean highest APS score during hospital stay was 23.9 and was not statistically different between the genotype

Table 1-Baseline Characteristics of 200 Patients With CAP by ACE I/D Polymorphism*

\begin{tabular}{|c|c|c|c|c|c|}
\hline Variables & All $(\mathrm{n}=200)$ & $\mathrm{II}(\mathrm{n}=42)$ & ID $(n=106)$ & $\mathrm{DD}(\mathrm{n}=52)$ & $\mathrm{p}$ Value \\
\hline \multicolumn{6}{|l|}{ Demographics } \\
\hline Age, yr & $63 \pm 17$ & $61 \pm 17$ & $65 \pm 17$ & $60 \pm 18$ & 0.224 \\
\hline Male gender & $124(62)$ & $20(48)$ & $70(66)$ & $34(65)$ & 0.097 \\
\hline \multicolumn{6}{|l|}{ Comorbidity } \\
\hline Renal disease & $10(5)$ & $2(5)$ & $4(4)$ & $4(8)$ & 0.567 \\
\hline Congestive heart failure & $18(9)$ & $3(7)$ & $9(9)$ & $6(12)$ & 0.734 \\
\hline Diabetes & $34(17)$ & $7(17)$ & $20(19)$ & $7(14)$ & 0.695 \\
\hline Lung diseases & $70(35)$ & $18(43)$ & $38(36)$ & $14(27)$ & 0.264 \\
\hline ACE/Angiotensin-II use & $43(22)$ & $7(17)$ & $28(26)$ & $8(15)$ & 0.197 \\
\hline Etiology & & & & & 0.402 \\
\hline Pneumococcal & $60(30)$ & $17(41)$ & $30(28)$ & $13(25)$ & \\
\hline Atypical & $21(11)$ & $5(12)$ & $11(10)$ & $5(10)$ & \\
\hline Viral & $16(8)$ & $3(7)$ & $11(10)$ & $2(4)$ & \\
\hline Gram-negative strain & $22(11)$ & $6(14)$ & $9(9)$ & $7(14)$ & \\
\hline Other & $8(4)$ & $0(0)$ & $4(4)$ & $4(8)$ & \\
\hline Unknown & $73(37)$ & $11(26)$ & $41(39)$ & $21(40)$ & \\
\hline PSI risk class* & & & & & 0.252 \\
\hline Low I & $30(15)$ & $7(17)$ & $15(14)$ & $8(15)$ & \\
\hline Low II & $34(17)$ & $8(19)$ & $16(15)$ & $10(19)$ & \\
\hline Low III & $53(27)$ & $4(10)$ & $35(33)$ & $14(27)$ & \\
\hline Moderate IV & $56(28)$ & $17(40)$ & $25(24)$ & $14(27)$ & \\
\hline High V & $27(13)$ & $6(14)$ & $15(14)$ & $6(12)$ & \\
\hline
\end{tabular}

*Data are presented as mean \pm SD or No. (\%). PSI is based on Fine et al. ${ }^{3}$ 
Table 2-Clinical Outcomes and Illness Severity by ACE I/D Polymorphism*

\begin{tabular}{|c|c|c|c|c|}
\hline Variables & $\begin{array}{c}\text { II } \\
(\mathrm{n}=42)\end{array}$ & $\begin{array}{c}\text { ID } \\
(\mathrm{n}=106)\end{array}$ & $\begin{array}{c}\text { DD } \\
(\mathrm{n}=52)\end{array}$ & $\mathrm{p}$ Value \\
\hline \multicolumn{5}{|l|}{ Clinical outcomes } \\
\hline $\begin{array}{l}\text { Duration of } \\
\text { stay, d }\end{array}$ & $11.5(4-49)$ & $9(2-143)$ & $9(3-59)$ & 0.548 \\
\hline ICU admittance & $7(17)$ & $11(10)$ & $3(6)$ & 0.230 \\
\hline Time in ICU, d & $5(1-13)$ & $8(3-64)$ & $4(4-16)$ & 0.282 \\
\hline $\begin{array}{l}\text { In-hospital } \\
\text { mortality }\end{array}$ & $2(5)$ & $6(6)$ & $2(4)$ & 0.883 \\
\hline $\begin{array}{l}\text { Twenty-eight } \\
\text { day mortality }\end{array}$ & $3(7)$ & $4(4)$ & $3(6)$ & 0.668 \\
\hline \multicolumn{5}{|l|}{ Illness severity } \\
\hline APS $\uparrow$ & $26 \pm 13$ & $23 \pm 12$ & $23 \pm 13$ & 0.350 \\
\hline ARDS & $1(2)$ & $3(3)$ & $0(0)$ & 0.481 \\
\hline
\end{tabular}

*Data are presented as No. (\%), median (range), or mean \pm SD. † Mean calculated based on highest score for each individual.

groups. There was no trend toward an association between ACE genotype and risk of ARDS. Figure 1 shows the mean APS scores during the episode of pneumonia by ACE genotype. Using one-way analysis of variance, the scores were not statistically different on any of the days $(\mathrm{p}=0.350)$. None of the patients in the low PSI risk classes (risk class I-II) died during hospital stay. For the patients with a moderate (risk class IV) or high risk (risk class V), the in-hospital mortality rates were $5.4 \%$ and $22.2 \%$, respectively. In univariate analysis, the risk class at admission was significantly associated with in-hospital mortality $(p<0.01)$. In the multivariate analyses, no associations between ACE I/D polymorphism and need for ICU admittance, in-hospital mortality, nor 28-day mortality could be detected as ACE genotype did not reach significance in any of the models. When ACE genotype (DD vs II+ID) was added to

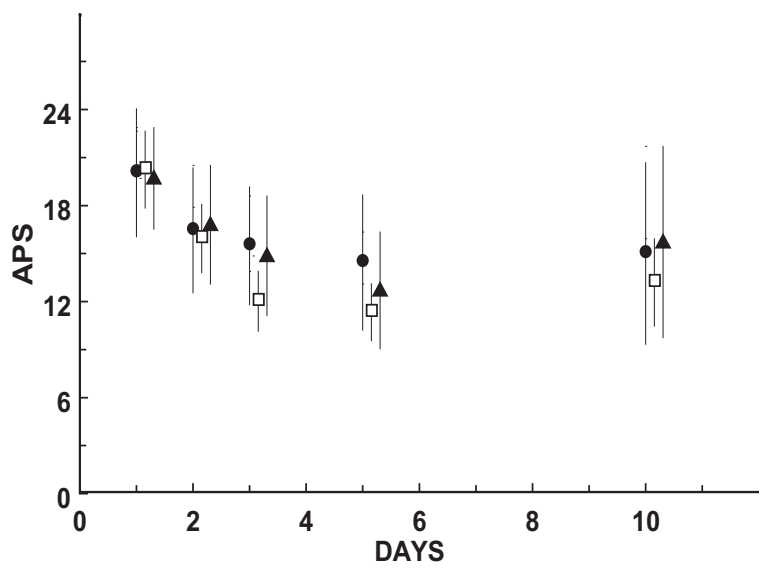

Figure 1. Mean APS scores with 95\% CIs by ACE genotype $(\boldsymbol{\nabla}=\mathrm{II}, \square=\mathrm{ID}, \boldsymbol{\Delta}=\mathrm{DD})$ on the day of hospital admission (day 1) and during hospital stay (days 2, 3, 5, and 10).
Table 3-Genotype and Allele Frequencies of the ACE I/D Polymorphism*

\begin{tabular}{lccc}
\hline \hline Variables & $\begin{array}{c}\text { Pneumonia } \\
(\mathrm{n}=200)\end{array}$ & $\begin{array}{c}\text { Control } \\
\text { Subjects }(\mathrm{n}=200)\end{array}$ & p Value \\
\hline Genotype & & & 0.973 \\
II & $42(21)$ & $43(22)$ & \\
ID & $106(53)$ & $107(54)$ & \\
DD & $52(26)$ & $50(25)$ & 0.832 \\
Allele & & & \\
I & $190(48)$ & $193(48)$ & \\
D & $210(52)$ & $207(52)$ & \\
\hline
\end{tabular}

*Data are presented as No. (\%).

the final model afterwards, this yielded odds ratios of 0.81 (95\% confidence interval [CI], 0.15 to 4.29 ), 1.53 (95\% CI, 0.34 to 6.86), and 0.47 (95\% CI, 0.12 to 1.77) for in-hospital mortality, 28-day mortality, and ICU admittance, respectively. Exclusion of patients using ACE inhibitors or angiotensin-II receptor blockers from the analyses did not cause a change in the findings (data not shown).

For both patients with pneumonia and control subjects, the ACE I/D genotype distribution was compatible with the Hardy-Weinberg equilibrium. The genotype and allele frequencies did not differ between patients and control subjects (Table 3).

\section{Discussion}

In this hospital-based prospective observational study, no differences in clinical development of CAP were observed between patients with the DD, ID, and II genotype of the ACE gene. Furthermore, there was a similar distribution of genotypes and allele frequencies of the ACE I/D gene in patients with pneumonia and control subjects, suggesting no association between the ACE I/D polymorphism and the risk of acquiring pneumonia.

The recent study of Morimoto et $\mathrm{al}^{21}$ found that the ACE D allele was an independent risk factor for pneumonia in elderly patients with a relative risk of 2.9 (95\% CI, 1.7 to 4.8). Although our study had sufficient power to detect an odds ratio $\geq 1.60$, we were not able to confirm this association. A major difference between the present study and the study from Morimoto et $\mathrm{al}^{21}$ is the ethnicity of the population under study. Morimoto et al ${ }^{21}$ studied Japanese patients solely, whereas we studied a Dutch white population. Reports have shown marked ethnic differences between polymorphisms of the reninangiotensin system components, especially of the ACE gene. ${ }^{27}$ The prevalence of the DD genotype is small in Asian populations compared to white and African populations. ${ }^{28}$ When we compare the ACE 
I/D genotype frequencies between our control group and the control group of Morimoto et al, ${ }^{21}$ we can confirm this difference (frequency of DD genotype: $25 \%$ vs $11 \% ; \mathrm{p}<0.001)$. The genotype frequency of our control group is very much in line with other white control groups published in literature. ${ }^{29,30}$ The ACE I/D polymorphism occurs in multiple haplotypes. Possibly, the ACE I/D polymorphism is not a functional polymorphism but rather a marker for a true functional polymorphism for which the linkage dysequilibrium with the true functional polymorphism is different between ethnic groups.

Another difference between the present study and the study of Morimoto et $\mathrm{al}^{21}$ is the setting of the study. Morimoto et al ${ }^{21}$ studied elderly inpatients in a long-term care hospital because of the known increased risk of pneumonia due to aspiration in this group of patients. Furthermore, they studied patients only for the nonwinter months in order include mostly aspiration events. Increased risk of aspiration through decreased activity of the cough reflex via decreased local levels of the protussive peptides bradykinin and substance $\mathrm{P}$ is proposed as one possible mechanism responsible for the effect of ACE D allele on pneumonia risk. ${ }^{18} \mathrm{We}$ think, however, that this difference cannot explain the finding of a null effect in the present study. Firstly, when we limited our analysis to nonwinter (April to November) events, the genotype distribution of the patients remained identical to that of the control subjects (II/ID/DD $=21 / 50 / 24 ; \mathrm{p}=0.929$ ). Secondly, the genotype distribution of the patients did not differ with age.

At last, the finding of a null effect could also be explained by the inclusion of admitted pneumonia cases solely. Approximately $60 \%$ of patients with pneumonia are treated at home. Therefore, one might argue that admission itself is dependent on genotype, either because those of one genotype (ie, DD) die before referral, or because those of one genotype (ie, II) are not sufficiently unwell to be admitted. Such admission bias, however, seems unlikely given that genotype distribution is in Hardy-Weinberg equilibrium and very similar to our control group.

Besides no association between ACE I/D polymorphism and pneumonia risk, our study also showed no association between the ACE I/D polymorphism and pneumonia outcome. The pneumonia illness severity, as quantified by APS, was not different for the three genotype groups as was the duration of hospital stay, in-hospital mortality, and 28-day mortality. Harding et $\mathrm{al}^{31}$ showed that the ACE D allele is associated with increased risk of organ dysfunction and death with meningococcal meningitis. Another study from Marshall et al ${ }^{32}$ suggested an important role for the ACE I/D polymorphism in the susceptibility and outcome in ARDS. This was partly confirmed by Jerng et al, ${ }^{33}$ who concluded that the ACE I/D polymorphism is a prognostic factor for the outcome of ARDS. Also, Adamzik et al ${ }^{29}$ showed an association between the ACE DD genotype and increased 30-day mortality in ARDS. In the present study, we were not able to extend these findings to CAP. There was no trend toward an association between ACE I/D polymorphism and the occurrence of ARDS in our patients (Table 2). This is in accordance with the previous findings from Jerng et $\mathrm{al}^{33}$ and Adamzik et al. ${ }^{29}$ Due to limited numbers, we were unable to examine the association between ACE I/D polymorphism and outcome in ARDS.

Regarding the association between the ACE I/D polymorphism and clinical outcome of CAP, we realize that the numbers of outcomes in the present study were smaller than expected and that this could explain the finding of a null effect due to lack of power. The absence of any trend toward an effect of ACE DD genotype on pneumonia outcome makes the need for additional studies with larger numbers questionable. Also, a subgroup analysis (data not shown) in patients with confirmed pneumococcal pneumonia showed no trend of an effect of ACE genotype on disease severity. Our study still had sufficient power to detect a $10 \%$ absolute difference in mortality between the DD and ID+II genotypes. In conclusion, according to our findings, the ACE gene I/D polymorphism is not associated with risk and outcome of CAP in a Dutch white population.

\section{REFERENCES}

1 Fine MJ, Smith MA, Carson CA, et al. Prognosis and outcomes of patients with community-acquired pneumonia: a meta-analysis. JAMA 1996; 275:134-141

2 Mortensen EM, Coley CM, Singer DE, et al. Causes of death for patients with community-acquired pneumonia: results from the Pneumonia Patient Outcomes Research Team cohort study. Arch Intern Med 2002; 162:1059-1064

3 Fine MJ, Auble TE, Yealy DM, et al. A prediction rule to identify low-risk patients with community-acquired pneumonia. N Engl J Med 1997; 336:243-250

4 File TM Jr, Tan JS. Pneumonia in older adults: reversing the trend. JAMA 2005; 294:2760-2763

5 Fry AM, Shay DK, Holman RC, et al. Trends in hospitalizations for pneumonia among persons aged 65 years or older in the United States, 1988-2002. JAMA 2005; 294:2712-2719

6 Okaishi K, Morimoto S, Fukuo K, et al. Reduction of risk of pneumonia associated with use of angiotensin I converting enzyme inhibitors in elderly inpatients. Am J Hypertens 1999; 12:778-783

7 Ohkubo T, Chapman N, Neal B, et al. Effects of an angiotensin-converting enzyme inhibitor-based regimen on pneumonia risk. Am J Respir Crit Care Med 2004; 169:10411045

8 Mortensen EM, Restrepo MI, Anzueto A, et al. The impact of prior outpatient ACE inhibitor use on 30-day mortality for patients hospitalized with community-acquired pneumonia. BMC Pulm Med 2005; 5:12 
9 Johnson AR, Schulz WW, Noguiera LA, et al. Kinins and angiotensins: angiotensin I converting enzyme (kininase II) in endothelial cells cultured from human pulmonary arteries and veins. Clin Exp Hypertens 1980; 2:659-674

10 Morice AH, Lowry R, Brown MJ, et al. Angiotensin-converting enzyme and the cough reflex. Lancet 1987; 2:1116-1118

11 Kranzhofer R, Browatzki M, Schmidt J, et al. Angiotensin II activates the proinflammatory transcription factor nuclear factor- $\kappa \mathrm{B}$ in human monocytes. Biochem Biophys Res Commun 1999; 257:826-828

12 Phillips MI, Kagiyama S. Angiotensin II as a pro-inflammatory mediator. Curr Opin Investig Drugs 2002; 3:569-577

13 Suzuki Y, Ruiz-Ortega M, Lorenzo O, et al. Inflammation and angiotensin II. Int J Biochem Cell Biol 2003; 35:881-900

14 Das UN. Is angiotensin-II an endogenous pro-inflammatory molecule? Med Sci Monit 2005; 11:RA155-RA162

15 Das UN. Angiotensin-II behaves as an endogenous proinflammatory molecule. J Assoc Physicians India 2005; 53: 472-476

16 Arndt PG, Young SK, Worthen GS. The angiotensin converting enzyme regulates lipopolysaccharide-induced pulmonary neutrophil influx through bradykin and plasminogen activator inhibitor-1 pathways [abstract]. Proc Am Thor Society 2006; 3:A337

17 Rigat B, Hubert C, Alhenc-Gelas F, et al. An insertion/ deletion polymorphism in the angiotensin I-converting enzyme gene accounting for half the variance of serum enzyme levels. J Clin Invest 1990; 86:1343-1346

18 Brown NJ, Blais C Jr, Gandhi SK, et al. ACE insertion/ deletion genotype affects bradykinin metabolism. J Cardiovasc Pharmacol 1998; 32:373-377

19 Takahashi T, Yamaguchi E, Furuya K, et al. The ACE gene polymorphism and cough threshold for capsaicin after cilazapril usage. Respir Med 2001; 95:130-135

20 Reyes-Engel A, Morcillo L, Aranda FJ, et al. Influence of gender and genetic variability on plasma angiotensin peptides. J Renin Angiotensin Aldosterone Syst 2006; 7:92-97

21 Morimoto S, Okaishi K, Onishi M, et al. Deletion allele of the angiotensin-converting enzyme gene as a risk factor for pneumonia in elderly patients. Am J Med 2002; 112:89-94

22 Utrecht province: facts and figures 2006 [in Dutch]. Utrecht, the Netherlands; Geografiek, 2007

23 Kruit A, Grutters JC, Gerritsen WB, et al. ACE I/D-corrected
Z-scores to identify normal and elevated ACE activity in sarcoidosis. Respir Med 2007; 101:510-515

24 Knaus WA, Wagner DP, Draper EA, et al. The APACHE III prognostic system: risk prediction of hospital mortality for critically ill hospitalized adults. Chest 1991; 100:1619-1636

25 Lindpaintner K, Pfeffer MA. Molecular genetics crying wolf? The case of the angiotensin-converting enzyme gene and cardiovascular disease. J Am Coll Cardiol 1995; 25:1632-1633

26 Somogyvari F, Szolnoki Z, Marki-Zay J, et al. Real-time PCR assay with fluorescent hybridization probes for exact and rapid genotyping of the angiotensin-converting enzyme gene insertion/deletion polymorphism. Clin Chem 2001; 47:17281729

27 Pereira AC, Mota GA, Bensenor I, et al. Effect of race, genetic population structure, and genetic models in two-locus association studies: clustering of functional renin-angiotensin system gene variants in hypertension association studies. Braz J Med Biol Res 2001; 34:1421-1428

28 Sagnella GA, Rothwell MJ, Onipinla AK, et al. A population study of ethnic variations in the angiotensin-converting enzyme I/D polymorphism: relationships with gender, hypertension and impaired glucose metabolism. J Hypertens 1999; 17:657-664

29 Adamzik M, Frey U, Sixt S, et al. ACE I/D but not AGT (-6)A/G polymorphism is a risk factor for mortality in ARDS. Eur Respir J 2006

30 Biller H, Zissel G, Ruprecht B, et al. Genotype-corrected reference values for serum angiotensin-converting enzyme. Eur Respir J 2006; 28:1085-1090

31 Harding D, Baines PB, Brull D, et al. Severity of meningococcal disease in children and the angiotensin-converting enzyme insertion/deletion polymorphism. Am J Respir Crit Care Med 2002; 165:1103-1106

32 Marshall RP, Webb S, Bellingan GJ, et al. Angiotensin converting enzyme insertion/deletion polymorphism is associated with susceptibility and outcome in acute respiratory distress syndrome. Am J Respir Crit Care Med 2002; 166: $646-650$

33 Jerng JS, Yu CJ, Wang HC, et al. Polymorphism of the angiotensin-converting enzyme gene affects the outcome of acute respiratory distress syndrome. Crit Care Med 2006; 34:1001-1006 
Angiotensin-Converting Enzyme Insertion/Deletion Polymorphism and Risk and Outcome of Pneumonia

Ewoudt M. W. van de Garde, Henrik Endeman, Vera H. M. Deneer, Douwe H. Biesma, Fakhredin A. Sayed-Tabatabaei, Henk J. T. Ruven, Hubert G. M. Leufkens and Jules M. M. van den Bosch

Chest 2008;133;220-225; Prepublished online October 1, 2007;

DOI 10.1378/chest.07-1400

This information is current as of January 10, 2008

\begin{tabular}{|ll|}
\hline $\begin{array}{l}\text { Updated Information } \\
\text { \& Services }\end{array}$ & $\begin{array}{l}\text { Updated information and services, including } \\
\text { high-resolution figures, can be found at: } \\
\text { http://chestjournal.org/cgi/content/full/133/1/220 }\end{array}$ \\
This article cites 31 articles, 11 of which you can access \\
for free at: \\
http://chestjournal.org/cgi/content/full/133/1/220\#BIBL \\
Permissions \& Licensing & $\begin{array}{l}\text { Information about reproducing this article in parts } \\
\text { (figures, tables) or in its entirety can be found online at: } \\
\text { http://chestjournal.org/misc/reprints.shtml } \\
\text { Information about ordering reprints can be found online: } \\
\text { http://chestjournal.org/misc/reprints.shtml }\end{array}$ \\
Email alerting service & $\begin{array}{l}\text { Receive free email alerts when new articles cite this } \\
\text { article sign up in the box at the top right corner of the } \\
\text { online article. }\end{array}$ \\
Images in PowerPoint format & $\begin{array}{l}\text { Figures that appear in CHEST articles can be } \\
\text { downloaded for teaching purposes in PowerPoint slide } \\
\text { format. See any online article figure for directions. }\end{array}$ \\
&
\end{tabular}

A M E R I C A N C O L L E G E O F

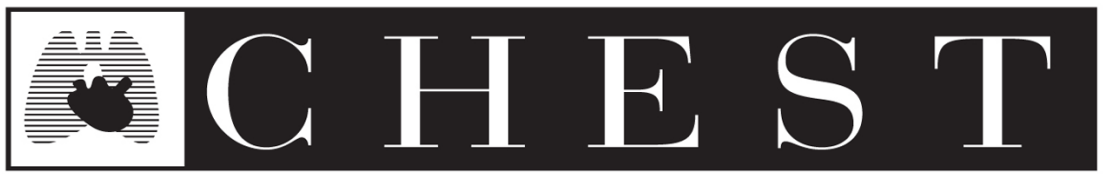
$\begin{array}{llllllllll}\mathrm{P} & \mathrm{H} & \mathrm{Y} & \mathrm{S} & \mathrm{I} & \mathrm{C} & \mathrm{I} & \mathrm{A} & \mathrm{N} & \mathrm{S}\end{array}$ 